\title{
EFFICACY OF T-2 TOXIN DETOXIFYING AGENT IN BROILER CHICKENS
}

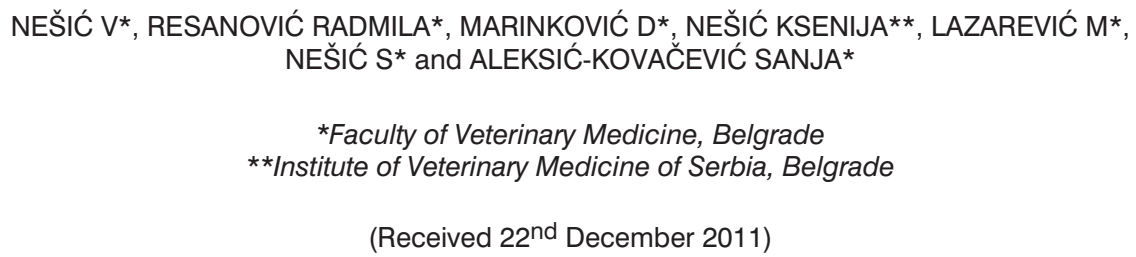

This investigation was conducted in order to investigate the efficacy of the detoxifying agent Mycofix ${ }^{\circledR}$ Plus (MP) in the prevention and/or alleviation in vivo adverse effects of T-2 toxin in broilers. In addition, the adsorbing potential of MP was estimated in vitro. Mean degradation levels of T-2 toxin with MP in vitro, as measured by HPTLC, varied from 26.06 to $31.02 \%$ and the adsorption ability was elevated in acidic environment ( $\mathrm{pH}$ 3). In vivo trial was performed on 160 one day old "Ross" broiler chicks and lasted for 21 days. Birds were divided into 4 equal groups as follows: Group 1 - negative control; Group 2 positive control - 2 ppm T-2 toxin; Group 3 - 2 ppm T-2 toxin + 2 kg/t MP; Group $4-2 \mathrm{~kg} / \mathrm{t} \mathrm{MP}$.

Broilers fed the diet containing $2 \mathrm{mg} / \mathrm{kg}$ of $\mathrm{T}-2$ toxin without MP developed typical T-2 toxicosis. Birds that were fed the diet containing both T-2 and MP had better performances and no oral ulcerations as the dominant sign of T-2 toxicosis were observed. Histopathological examination of tissues originating from birds fed the diet containing T-2 toxin revealed degenerative changes in the oral and small intestine mucosa, necroses of enterocytes and hepatocytes, as well as depletion of lymphocytes in the bursa Fabricii. Immunohistochemical examination also revealed negative effects of $T-2$ toxin on cells proliferation in intestineal and bile duct mucosa, as well as on lymphocytes from bursa Fabricii. The macroscopic and microscopic structure of the liver, intestine and bursa Fabricii of broilers fed a diet containing T-2 toxin and MP was mostly preserved. Cutaneous basophile hypersensitivity reaction was weaker in broilers fed mixtures containing $2 \mathrm{mg} / \mathrm{kg}$ T-2 toxin.

Key words: broiler chickens, detoxification, Mycofix, T-2 toxin

\section{INTRODUCTION}

Trichothecenes have a tetracyclic structure, with a sesquiterpenoid 12,13epoxytrichothec-9-ene ring system and they are arbitrarily divided into four groups: A, B, C and D according to their chemical composition (Ueno, 1977). In 
general, the trichothecenes of type A are more toxic than those of type B and T-2 toxin is the most toxic of the commonly detected trichothecenes (Scott, 1990).

$\mathrm{T}-2$ toxin causes oral lesions, resulting in reduced feed intake, weight gain, growth rate and body weight (Lesson, 1995). Biological expression of negative effects of T-2 toxin is reflected in cytotoxic, dermotoxic and immunosuppressive effects. T-2 toxin leads to DNA and RNA synthesis inhibition, most probably secondary, through the inhibition of protein synthesis (Eriksen and Petterson, 2004). T-2 toxin is known to suppress both cellular and humoral immune response (Pestka et al., 2004) and there is also evidence that T-2 toxin induces apoptosis in a number of cell types with high proliferative activity (Doi et al., 2006).

There are three possible ways to prevent effects of mycotoxins in contaminated feed: prevention of contamination by plant cultivation or preharvest use of fungicides, by decontamination of mycotoxin containing feed by the use of physical, chemical or microbiological methods and finnaly by inhibition of absorption of mycotoxins in the consumed feed in the gastrointestinal tract (Huwig et al., 2001). When contamination can not be prevented, decontamination is needed and this is especially important for chicken, because cereals and grains are the main consituents of their feed mixtures. Physical adsorption is not sufficient for the detoxification of trichothecenes while chemical methods are expensive and affect grain quality (Piva et Galvano, 1999). A remarkable alternative to detoxification is microbial degradation of mycotoxins by bacteria. Physical adsorption and microbial degradation both take place in the intestine of the animal consuming mycotoxin contaminated feed (Karlovski, 1999).

Detoxifying agents, added to mycotoxin contaminated diets, are expected to adsorbe and/or degrade mycotoxins in situ under $\mathrm{pH}$, temperature and moisture conditions of the digestive tract. Detoxifying agent Mycofix ${ }^{\circledR}$ Plus (MP) is a feed additive with adsorbing properties which was upgraded by the addition of enzymes (de-epoxydase and lactonase) in order to cope with the more non-polar mycotoxins like T-2 toxin. In this way, T-2 transforms to inactive de-epoxy-HT-2 toxin by deacetylation, through the intermediate HT-2 toxin (Fuchs et al., 2002).

Investigations of the efficacy of the detoxifying agent MP in alleviating harmful effects of T-2 toxin in broiler chickens, conducted by numerous authors proved its positive effect on birds health and performances (Diaz, 2002; Garcia et al., 2003; Diaz et al., 2005; Cortyl and Heidler, 2006, Xue et al., 2010). However, according to Dänicke et al. (2003) addition of MP, as detoxifying agent for adsorption or deactivation of mycotoxins, had no significant influence on specific mycotoxin effects, especially when it comes to Fusarium toxins. Also, Karlovski (1999) failed to detect in vitro activity of de-epoxydase in MP, which should open the epoxy ring of trichothecenes and deactivate them. This was attributed to feed preparation technology especially pellets, thus reducing the efficiency of this additive.

This study was aimed to provide detailed insight into performance, health status, pathomorphological changes and cutaneous basophile hypersensitivity reaction (CBHR) to phytohemagglutinin (PHA) in broiler chicken exposed to relatively low doses of T-2 toxin (2 ppm), as well as the possibility of preventing or alleviating its harmful effects by detoxifying agent MP. 
Acta Veterinaria (Beograd), Vol. 62, No. 2-3, 171-182, 2012.

\section{MATERIALS AND METHODS}

T-2 toxin isolation and feed contamination

Pure T-2 toxin isolate, was obtained under laboratory conditions by cultivation of Fusarium sporotrichoides, from 4 isolates: ITM-496, KF-38/1, M-1-1 and R-2301 (Bočarov-Stančić and Radošević, 1991) and used for feed contamination. To achieve proper homogenization of T-2 toxin in the feed, ethylacetate extract which contained 2 ppm of T-2 toxin was 3 times sprayed on a smaller amount of feed that was afterwards mixed into the rest of the feed mixture needed for the trial period of 21 days. The T-2 toxin was mixed into broiler feed with a twin-shell blender and homogenized to reach contamination level of 2 ppm T-2 toxin for groups 2 and 3 . Following proper preparation of the feed samples, determination of T-2 toxin amount was performed by ELISA method (Neogen, USA).

In vitro assay

In vitro investigation of the MP efficacy in deactivating T-2 toxin was performed by addition of $0.05 \mathrm{mg}$ basic standard of T-2 toxin solution $(1 \mathrm{mg} / \mathrm{mL}$ in ethyl-acetate) and $100 \mathrm{mg}$ of the tested detoxifying agent to $10 \mathrm{~mL}$ of basic solution. Contact between T-2 toxin and MP was reached by means of a magnetic mixer, in PBS (phosphate buffer solution - $\mathrm{pH} 7$ ) or phthalate buffer solution (potassium hydrogen phthalate - $\mathrm{pH} 4$ ) where $\mathrm{HCl}$ was added to obtain $\mathrm{pH} 3$. This was performed at $37^{\circ} \mathrm{C}$, over $1 \mathrm{~h}$. Determination of "free" i.e. unbound and nondegradated T-2 toxin was accomplished by HPTLC (High Performance Thin Layer Chromatography). Prepared samples were inflicted on chromatographic panes Silikagel 60 F254 HPTLC (Merck, Germany). The chromatogram was further on processed in the toluene-ethyl acetate-formic acid (50:40:10 v/v/v) system. Fluorescence was raised following splashing by $25 \%$ solution of sulfuric acid in methanol. Densitometric determination of T-2 toxin amount was performed by TLC Scanner densitometer (Camag, Switzerland) at 254 and $366 \mathrm{~nm}$ using software system Cats III.

In vivo assay

Animals and experimental design. All diets were tested for broiler performance in a single floor battery with male Ross 308 broilers from day 1 to 21 of age. A total of 160 male 1-d-old chicks were randomly distributed to dietary treatments with 40 chicks per group. Temperature and lighting regimen were in accordance with the recommendations of the breeder. Feed and water were provided ad libitum. Birds were fed standard comercial mixture (Table 1) with added T-2 toxin or MP, as follows: Group 1: negative control; Group 2: positive control - 2 ppm T-2 toxin; Group 3: 2 ppm T-2 toxin + 2 kg/t MP; Group 4: 2 kg/t MP. During the experiment, basic performances (body weight, feed intake and feed conversion) were calculated and health status of broilers was observed daily. 
Table 1. Chemical composition of the broiler feed mixture

\begin{tabular}{|c|c|c|c|c|c|c|c|c|c|}
\hline $\begin{array}{c}\text { Chemical } \\
\text { composition }\end{array}$ & Water & Ash & Proteins & Fat & Cellulose & FNE & Ca & $P$ & $\begin{array}{c}\mathrm{ME} \\
\mathrm{MJ} / \mathrm{kg}\end{array}$ \\
\hline \hline \% of mixture & 10.90 & 6.42 & 21.87 & 6.62 & 2.99 & 51.20 & 0.98 & 0.81 & 13.09 \\
\hline
\end{tabular}

FNE - free nitrogen extract; ME - metabolizable energy

Histopathology. At day 21 of the trial all birds were sacrificed by cutting the jugular vein after manual stunning in order to obtain samples for histopathological and immunohistochemical investigations. Samples of liver, small intestine and bursa of Fabricius from each bird were fixed in 10\% neutral buffered formalin and automatically processed for microscopic evaluation. All organ sections were stained using the standard hematoxylin eosin method and observed under the optical microscope (Olympus BX-41, Japan) at magnitude of 20x.

Immunohistochemistry. Immunohistochemical testing was performed on formalin fixed and paraffin embedded tissue samples of the small intestine, liver and bursa of Fabricius in all groups of broilers at day 21. A streptavidin-biotin immunohistochemical procedure was used (LSAB2) to mark CD3 (T cells) and PCNA (Proliferating Cell Nuclear Antigen) of positive cells (DAKO Cytomation, USA).

Cutaneous basophile hypersensitivity reaction (CBHR). In order to examine degree of cellular immunity, a test for cutaneous basophile hypersensitivity reaction (CBHR) was performed on day 20 of the experiment by intradermal inoculation of $100 \mu \mathrm{g}$ PHA (INEP, Zemun) dissolved in $0.1 \mathrm{~mL}$ of phosphate buffered saline (PBS), in the skin between the $3^{\text {rd }}$ and $4^{\text {th }}$ finger of the left foot as described earlier (Corrier and De Loach, 1990, Lazarević et al., 2000, Tokić et al., 2007). The same amount of PBS was inoculated into the right foot at the same place and served as a control. Prior to inoculation, skin thickness was measured on both places by means of an adapted cutinometer. The skin thickness and swelling was measured $24^{\text {hrs }}$ later at the site of the inoculation. The difference between the degree of skin thickness of the left and right leg was calculated and taken as the CBHR in $\mathrm{mm}$.

Statistical analysis. The percentage of mycotoxin degradation, body weights and feed consumption were all analyzed by ANOVA and Tukey's test.

\section{RESULTS}

In vitro evaluation

Average value of adsorbed T-2 toxin by MP was $26.06 \%$ at $\mathrm{pH} 7$ and $31.20 \%$ at $\mathrm{pH} 3$ solution acidity (Table 2). Amounts of adsorbed T-2 toxin did not differ significantly between samples tested in solutions of the same acidity. Somewhat larger absorbance was noted in the solutions with lower acidity - $\mathrm{pH} 3$. 
Acta Veterinaria (Beograd), Vol. 62, No. 2-3, 171-182, 2012.

Nešić $V$ et al.: Efficacy of T-2 toxin detoxifying

agent in broiler chickens

Table 2. The amount and percent of $\mathrm{T}-2$ toxin adsorbed by $\mathrm{MP}(\mathrm{pH} 7$ and $\mathrm{pH} 3)$

\begin{tabular}{|c|c|c|c|}
\hline Sample* & $\begin{array}{c}\text { The amount of nonadsorbed } \\
\text { T-2 toxin, } \mu \mathrm{g}(\mathrm{T}-2 \text { rest) }\end{array}$ & $\begin{array}{c}\text { The amount of adsorbed } \\
\text { T-2 toxin, } \mu \mathrm{g}\end{array}$ & $\begin{array}{c}\% \text { adsorbed of } \\
\text { T-2 toxin** }\end{array}$ \\
\hline \hline $\mathrm{pH} 7$ & 36.82 & 12.98 & 26.06 \\
\hline $\mathrm{pH} \mathrm{3}$ & 34.26 & 15.54 & 31.20 \\
\hline
\end{tabular}

* Detected amount $49.8 \mu \mathrm{g}(\mathrm{T}-2 \mathrm{exp})$

** $\frac{(\mathrm{T}-2 \exp -\mathrm{T}-2 \text { rest) } \times 100 \%}{\mathrm{T}-2 \exp }$

$$
\mathrm{T}-2 \mathrm{exp}
$$

\section{Growth and feed efficiency}

Table 3. summarizes the average BW, body weight gain and feed:gain ratio of the 4 experimental treatments. At day 21 the experimental group receiving T-2 toxin had significantly $(p \leq 0.01)$ lower BW than the control group. Statistical difference between the control group and group T-2 + MP was at the level of $99 \%$ while between T-2 group and groups T-2 + MP, and MP was at the level of $99.9 \%$ $(p \leq 0.001)$, as shown in Table 3a. Daily body weight gain of broilers treated with T-2 toxin was significantly lower at the level of $99.9 \%(p \leq 0.001)$ from those who were protected with MP and comparing to MP group, as well. For the broilers fed with T-2 contaminated feed significant differences in body weight were noticed at the level of $99 \%(p \leq 0.01)$ when compared to the control (Table 3b). Feed intake was not significantly different among experimental groups $(p \geq 0.05)$. No significant differences in the feed:gain ratio were observed between the control group and the group receiving $T-2$ toxin combined with MP $(p \geq 0.05)$. There were no toxic effects of the detoxifying agent MP on the health status and performance of broilers (Group 4).

Table 3. Broilers performances at the end of trial (day 21)

\begin{tabular}{|l|c|c|c|}
\hline Group & $\begin{array}{c}\text { Body weight, g 21.d } \\
(\bar{X} \pm \text { Sd })\end{array}$ & $\begin{array}{c}\text { Daily body weight gain, g } \\
(\mathrm{X} \pm \mathrm{Sd})\end{array}$ & $\begin{array}{c}\text { Feed:gain, g:g } \\
(21 . \mathrm{d})\end{array}$ \\
\hline \hline 1. Control & $689.5 \pm 11.2$ & $30.78 \pm 0.38$ & 1.68 \\
\hline 2. T-2 & $600.4 \pm 62.6$ & $26.54 \pm 2.83$ & 1.75 \\
\hline 3. T-2 + MP & $662.5 \pm 54.7$ & $29.50 \pm 2.41$ & 1.71 \\
\hline 4. MP & $692.7 \pm 8.6$ & $30.94 \pm 0.28$ & 1.69 \\
\hline
\end{tabular}

Table 3a. Statistical significance of differences in broilers body weight at day 21

\begin{tabular}{|l|c|c|c|c|}
\hline Group & Control & T-2 & T-2 + MP & MP \\
\hline \hline T-2 & $p<0.05$ & $\star$ & $*$ & * \\
\hline T-2 + MP & $p<0.01$ & $p<0.001$ & $*$ & * \\
\hline MP & NS & $p<0.001$ & NS & * \\
\hline
\end{tabular}

NS - not significant 
Table 3b. Statistical significance of differences in broilers body daily weight gain up to day 21

\begin{tabular}{|l|c|c|c|c|}
\hline Group & Control & $\mathrm{T}-2$ & $\mathrm{~T}-2+\mathrm{MP}$ & $\mathrm{MP}$ \\
\hline \hline $\mathrm{T}-2$ & $p<0.01$ & $\star$ & $\star$ & * \\
\hline $\mathrm{T}-2+\mathrm{MP}$ & $\mathrm{NS}$ & $\mathrm{p} 0.001$ & $\star$ & * \\
\hline $\mathrm{MP}$ & $\mathrm{NS}$ & $\mathrm{P} 0.001$ & $\mathrm{NS}$ & * \\
\hline
\end{tabular}

NS - not significant

Gross pathology

In broilers that received T-2 toxin without a detoxifying agent, necrosis of the tip and the basis of the tongue was observed on the $15^{\text {th }}$ day of treatment. In some cases necrosis was also recorded on the base of the tongue in the region of the frenulum linguae (Figure 1). In animals that in addition to T-2 toxin received MP in the diet changes in the oral cavity were not identified.

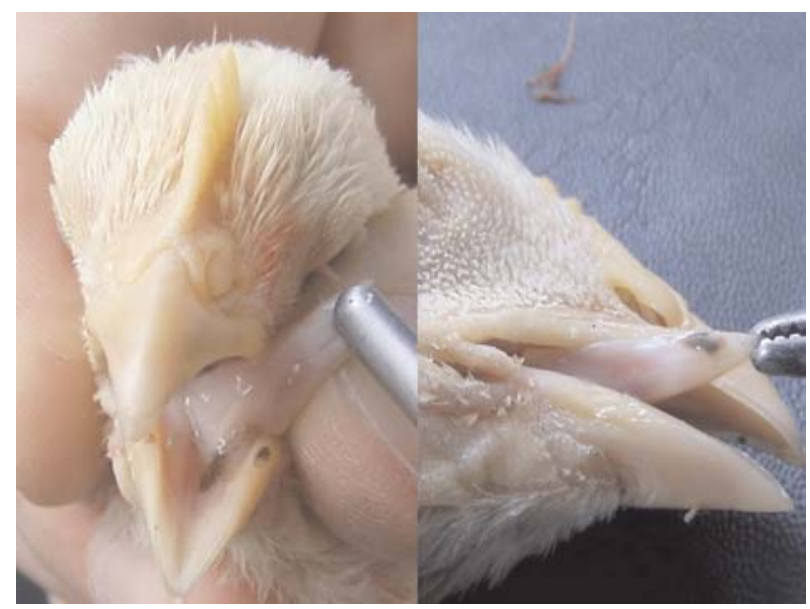

Figure 1. Group II, Necrosis in oral cavity, 15. day

Histopathology and immunohistochemical examinations

Histopathological examination of the liver tissue sections originating from broilers fed T-2 toxin contaminated feed without the detoxifying agent revealed massive, focal disseminated necrosis and numerous focal lymphocytic aggregates. In broilers fed diets containing both T-2 toxin and MP, a moderate hepatocyte degeneration was observed, mostly in the form of intracellular oedema and lymphocytic infiltration in the portal area were evident in only few birds (Figure 2a). Antigens of cell proliferation - PCNA were highly expressed both in hepatocytes and in epithelial cells of bile ducts in the form of brown nuclear precipitates visualized by diaminobenzidine $(D A B+)$. 
In the small intestine of broilers fed T-2 toxin contaminated feed degeneration and desquamation of enterocytes, as well as lymphocytic infiltration between intestine glandules were observed. Contrary to these results, in the small intestine of broilers fed T-2 contaminated feed with added MP adsorbent, protective effects were noticable and only moderate desquamation of enterocytes could be seen. The lenght and the structure of the small intestinal villi remained unchanged (Figure 2b). As judged by immunohistochemical methods the proliferative potential was not altered.

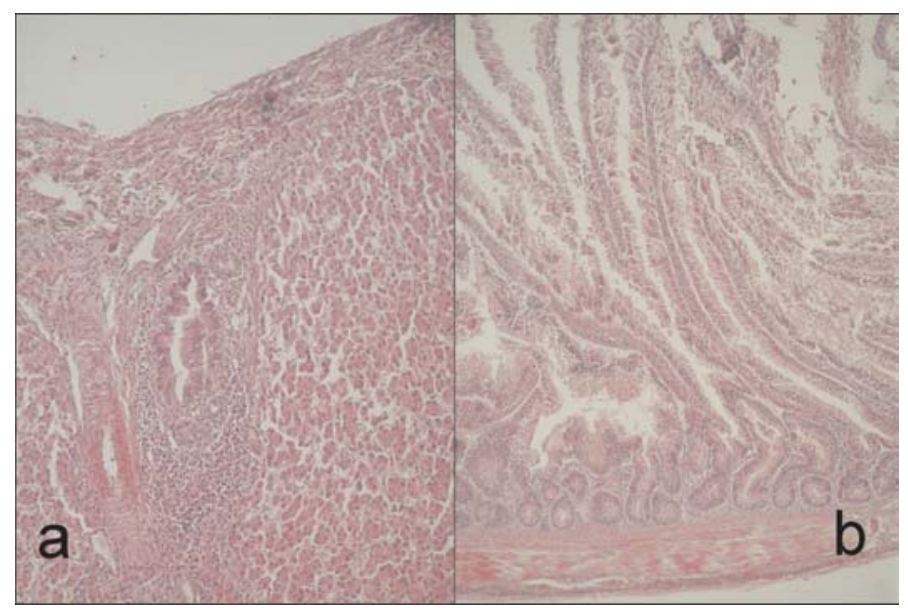

Figure 2. a) Liver, Group III, Intracellular oedema and Ly infiltration, HE, 20x;

b) Small intestine, Group III, Mild desquamation of enterocytes, HE, 20x

Histopathological examination of bursa Fabricii in broilers feed diets containing T-2 toxin without MP revealed atrophy of lymphoid tissue in the cortex and medulla, along with the vacuolization in the cortical lymphoepithelium and lymphocyte depletion in the medulla. In the tissue sections of bursa Fabricii originating from broilers fed diets containing both T-2 toxin and MP, we were able to notice preserved medullar and cortical structures, with dense lymphocyte population, especially expressed through diffuse proliferation of T-lymphocytes in the cortex of follicules (Figure 3a). In the bursa Fabricii of these birds the proliferative potential of PCNA cells was not altered (Figure 3b).

No histopathological alterations were noted in the control and MP groups.

Cutaneous basophile hypersensitivity reaction (CBHR)

The average value of the skin fold thickness, on day 21 of the experiment, in the experimental group of broilers that received only T-2 toxin was $0.37 \pm 0.08$ and this value was statistically different $(p<0.05)$ when compared to the control group $(0.57 \pm 0.16)$. Differences in CBHR between the control group and the groups fed mixtures containing both MP and T-2 toxin and MP $(0.47 \pm 0.20 ; 0.55 \pm 0.15$, respectively) were not significantly different $(\mathrm{p} \geq 0.05)$ (Table $4 a)$. 


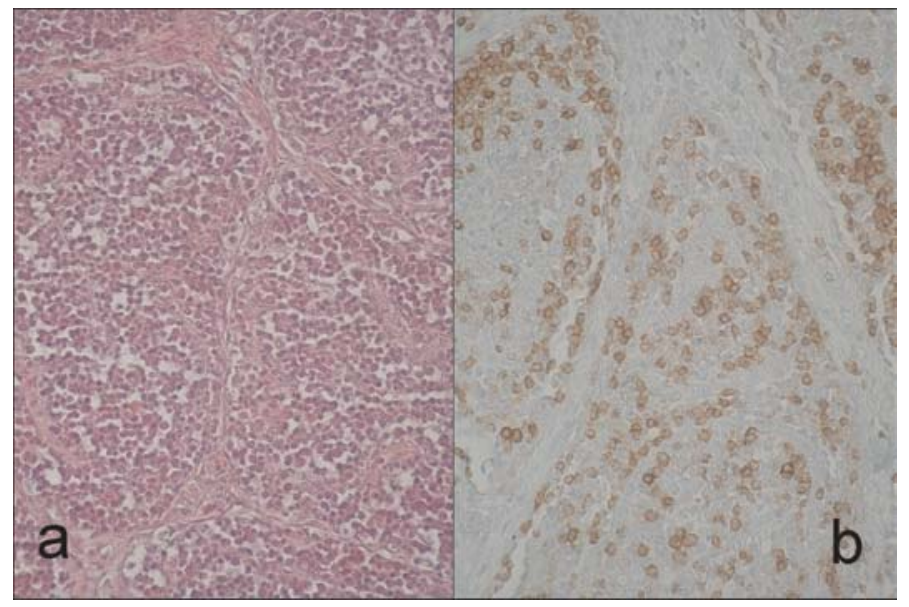

Figure 3. a) Bursa of Fabricius, Group III, Closely population of lymphocytes, HE, 20x;

b) Bursa of Fabricius, Group III, Expression of T lymphocytes, AEC, 20x

Table 4. Cutaneous basophile hypersensitivity reaction (CBHR) in experimental broilers $(n=6)$

\begin{tabular}{|l|c|c|c|c|c|c|}
\hline \multicolumn{1}{|c|}{ Group } & $\overline{\mathrm{X}}$ & $\mathrm{SD}$ & $\mathrm{Sx}$ & Minimum & Maximum & CV \% \\
\hline \hline 1. Control & 0.57 & 0.16 & 0.07 & 0.3 & 0.7 & 28.07 \\
\hline 2. T-2 & 0.37 & 0.08 & 0.03 & 0.2 & 0.4 & 21.62 \\
\hline 3. T-2 + MP & 0.47 & 0.20 & 0.08 & 0.2 & 0.7 & 42.55 \\
\hline 4. MP & 0.55 & 0.15 & 0.06 & 0.4 & 0.8 & 27.27 \\
\hline
\end{tabular}

${ }^{*} p<0.05$

Table 4a. Statistical significance of differences in CBHR in broilers on day 21

\begin{tabular}{|l|c|c|c|c|}
\hline Group & Control & T-2 & T-2 + MP & MP \\
\hline \hline T-2 & $p<0.05$ & $*$ & $*$ & $*$ \\
\hline T-2 + MP & NS & NS & $*$ & $*$ \\
\hline MP & NS & NS & NS & $*$ \\
\hline
\end{tabular}

NS - not significant

\section{DISCUSSION}

There is a strong need to use tests for the feed additives used in order to alleviate harmful effects of mycotoxins in in vitro and in vivo conditions, thus results of pathomorphological investigations are of special importance (Dale, 1998). 
In vitro simulation of conditions in the gastrointestinal tract might be difficult and sometimes it is not possible to create an appropriate physiological environment. Our results $(26.06 \%$ at $\mathrm{pH} 7$ and $31.20 \%$ at $\mathrm{pH} 3$ solution acidity) indicate a higher degree of deactivation of T-2 toxin by MP compared to the in vitro tests performed by Garcia et al. (2003), where the percentage of binding T-2 toxin to MP at pH 7, for 3 hours, was only 3.28\%. However, Scheideler (1993) and Dwyer et al. (1997) suggested that in vitro tests may not always be a reliable indicator of the ability of an adsorbent to bind mycotoxins.

T-2 toxin is well-known for its adverse effects on poultry performance (Eriksen and Petterson, 2004). The results of this study confirm these effects, since 2 ppm dietary T-2 toxin significantly decreased 21-d BW gain and increased feed:gain ratio. However, adverse effects on performance were almost completely overwhelmed by dietary supplementation with $2.0 \mathrm{~kg} / \mathrm{t}$ of MP. The results of the present study also confirm findings from previous trials in which was documented that MP is capable of counteracting the adverse effects of T-2 toxin (Diaz et al., 2005, Garcia et al., 2003, Cortyl and Heidler, 2006, Xue et al., 2010).

The absence of characteristic pathological changes in the oral cavity in broilers fed diets containing MP along with the relatively low concentration of T-2 toxin (1-2 mg/kg), was also reported by Garcia et al. (2003) and Diaz et al. (2005). The positive effect of this feed additive was also recorded in the case of strong contamination ( $>6 \mathrm{mg} / \mathrm{kg}$ ) when the body weight of broilers, which were given MP to contaminated feed, was higher comparing to the group that received only T-2 toxin, despite the presence of damage and ulceration in the oral cavity (Cortyl and Heidler, 2006).

It was documented that during metabolic changes, BBSH 797 (as a constituent of MP) produces enzymes, i.e. de-epoxydases, which degrade trichothecenes by selective destruction of their toxic 12.13-epoxy group. It is well known that the 12.13-epoxy trichothecene ring is responsible for its toxicity and addition of specific enzymes (de-epoxydase) consequently leads to a significant reduction in toxicity. In this way, T-2 toxin transforms in to the inactive de-epoxy-HT2 toxin by deacetylation, through intermediate HT-2 toxin (Fuchs et al., 2002).

Protective effects on the liver exerted by MP were also noted in the study of Garcia et al. (2003) who observed toxic effects on bile ducts epithelia in the portal area in intoxicated broilers. This beneficial effect was based on both enzymatic inactivation of the 12,13-epoxide ring of the trichothecenes and presence of flavonoligands which are one of the MP components. They protect liver tissue by blocking receptors in hepatocyte cells membrane.

One of the most important targets in T-2 toxicosis is the digestive tract (Jaćević et al., 2010). In our study, changes in the intestine were directly connected to T-2 toxin presence in the feed, as a consequence of inhibited proliferation of rapidly dividing cells. It was the main cause of growth depression in the group of broilers given T-2 toxin only $(p \leq 0.01)$, and in the less expressed form in the group $\mathrm{T}-2$ toxin $+M P(p \leq 0.05)$. However, despite moderate desquamation in the group T-2 toxin + MP, the appearance of the intestinal villi was normal. 
Exerted protective effects on bursa of Fabricius established in broilers fed mixtures containing detoxifying agent can be explained by the fact that, besides the biological constituent, MP contains an inorganic binder, with the adsorption based on production of hidrating links between the mycotoxin and the adsorbent. Flavonoligands, terpenoid complexes and fycofite components in addition reduce inflammation, stimulate immune response and accelerate metabolic processes (Liske et al., 2000, Binder et al., 2001).

Using immunohistological methods adverse effects of T-2 toxin are manifested by reducing proliferative activity of cells in the intestinal and bile duct mucosa and also on lymphocytes in the bursa of Fabricius. Beside PCNA expression, the presence of CD3 + T lymphocytes was immunohistochemically investigated in order to document the preservation of medullar and cortical structures in the bursa of Fabricius in all groups. Observed changes are morphologically comparable with those described for some chicken viral diseases (Velhner et al., 2010).

Cutaneous basophile hypersensitivity reaction was weaker in broilers fed mixtures containing $2 \mathrm{mg} / \mathrm{kg}$ T-2 toxin. Results of the CBHR were improved when MP was added in the contaminated diet. This is most probably the result of T-2 mycotoxin binding and/or indirect effect on cellular immune response through the activation of $B$ and $T$ cells, and macrophages.

It can be concluded that detoxifying agent MP was capable of counteracting the adverse effects on broilers performances caused by the dietary administration of 2 ppm T-2 toxin. These results also showed that histopathological and immunohistochemical examination can be very useful in the diagnosis of mycotoxicosis, especially when relatively small amounts of mycotoxins are present in the feed.

Address for correspondence:

Dr. Nešić Vladimir, Associate Professor

Department of Forensic Veterinary Medicine

Faculty of Veterinary Medicine, Belgrade,

Bulevar oslobođenja 18,

11000 Belgrade, Serbia

E-mail: nesic@vet.bg.ac.rs

\section{REFERENCES}

1. Binder EM, Heidler D, Schatzmayr G, Thimm N, Fusch E, Schuch M et al., 2001, Microbial detoxification in animal feed, Proc 10th Inter IUPAC Symp on mycotoxins and phycotoxins, 271-7.

2. Bočarov-Stančić $A$, Radošević $P, 1991$, Upoređivanje dva različita postupka ekstrakcije T-2 toksina iz tečne fermentacione podloge upotrebljene za kultivaciju toksikogenih fusarija, IV naučni skup o mikotoksinima, Sarajevo, 23-8.

3. Corrier DE, De Loach JR, 1990, Interdigital skin test for evaluation of delayed hypersensitivity and cutaneous basophil hypersensitivity in young chickens, Am J Vet Res, 6, 950-4.

4. Cortyl M, Heidler D, 2006, Prevention and control of feed industry mycotoxins, Processing feed and quality control, ASA, 50-7.

5. Dale N, 1998, Mycotoxin binders: It's time for real science, Poultry Digest, 57, 38-9. 
6. Dänicke S, Matthes S, Halle I, Ueberschär KH, Döll S, Valenta H, 2003, Effects of graded levels of Fusarium toxin-contaminated wheat and of a detoxifying agent in broiler diets on performance, nutrient digestibility and blood chemical parameters, Brit Poult Sci, 44, 113-26.

7. Diaz GJ, Cortes, Roldãn L, 2005, Evaluation of the efficacy of four feed additives against the adverse effects of T-2 toxin in growing broiler chickens, J Appl Poult Res, 14, 226-31.

8. Diaz GJ, 2002, Evaluation of the efficacy of a feed additive to ameliorate the toxic effects of 4,15diacetoxiscirpenol in growing chicks, Poult Sci, 81, 1492-5.

9. Doi K, Shinozuka J, Sehata S, 2006, T-2 toxin and apoptosis, J Toxic Path, 19, 15-27.

10. Dwyer MR, Kubena LF, Harvey RB, Mayura K, Sarr AB, Buckley S et al., 1997, Effects of inorganic adsorbents and cyclopiazonic acid in broiler chicks, Poult Sci, 76, 1141-9.

11. Eriksen GS, Pettersson H, 2004, Toxicological evaluation of trichothecenes in animal feed, Anim Feed Sci Tech, 114, 205-39.

12. Fuchs E, Binder EM, Heidler D, Krska R, 2002, Structural characterization of metabolites after the microbial degradation of type A trichothecens by the bacterial strain BBSH 797, Food Addit Contam, 19, 4, 379-86.

13. Garcia AR, Avila E, Rosiles R, Petrone VM, 2003, Evaluation of two mycotoxin binders to reduce toxicity of broiler diets containing ochratoxin A and T-2 toxin contaminated grain, Avian Dis, 47, 691-9.

14. Huwig A, Freimund S, Käppeli O, Dutler H, 2001, Mycotoxin detoxication of animal feed by different adsorbents. Toxicol Lett, 122, 179-88.

15. Jaćević VM, Resanović RD, Bočarov-Stančić A, Đorđević S, Dragojević-Simić V, Vukajlović A et al., 2010, Gastroprotective Effects of Novel Antidotal Combination in Rats Acutely Poisoned by T-2 Toxin, Acta Veterinaria, 60, 5-6, 461-78.

16. Karlovsky $P, 1999$, Biological detoxification of fungal toxins and its use in plant breeding, feed and food production, Nat Toxins, 7, 1-23.

17. Lazarević M, Žikić $D$, Ušćebrka G, 2000, The influence of long term sound stress on the blood leukocyte count, heterophyl/lymphocyte ratio and cutaneous basophil hypersensitive reaction to phytohemagglutinin in broiler chickens, Acta Veterinaria, 50, 2-3, 63-76.

18. Leeson SG, Diaz G, Summers JD, 1995, Trichothecenes, In: Poultry metabolic disorders and mycotoxins, University books, Guelph, Canada, 190-226.

19. Liske RB, Niessen L, Vogel RF, 2000, Potential of lactic acid bacteria to reduce the growth of Fusarium culmorum in the malting process, Proc 22nd Mycotoxin Workshop, 62-5.

20. Noy Y, Sklan D, 1995, Digestion and absorption in the young chick, Poult Sci, 74, 366-73.

21. Pestka JJ, Zhou HR, Moon Y, Chung YJ, 2004, Cellular and molecular mechanisms for immune modulation by deoxynivalenon and other trichothecenes: Unraveling a paradox, Toxicol Lett, 153, 61-73.

22. Piva A, Galvano F, 1999, Managing mycotoxin impact: Nutritional approaches to reduce the impact of mycotoxins. In: Lyons T.P., Jacques K.A. (Eds.), Proceeding of Altech's 15th Annual Symposium, Nottingham University Press, Nottingham, UK, 381-99.

23. Scheideler SE, 1993, Effects of various types of aluminosilicates and aflatoxin B1 on aflatoxin toxicity, chick performance, and mineral status, Poult Sci, 72, 282-8.

24. Scott PM, 1990, Trichothecenes in grains, The American Association of Cereal Chemists, Cereal Foods World, 35, 661-6.

25. Tokić V, Lazarević M, Sinovec Z, Tokić A, 2007, The influence of different feed additives on performances and immune response in broiler chicken, Acta veterinaria, 57, 2-3, 217-29.

26. Ueno $Y, 1977$, Trichothecenes: overview address. In: Mycotoxins in Human and Animal Health, Rodricks, J.V., Hesseltine, C.W. and Mehlman, M.A. (ed.), Pathotox Publishers, Inc, 189-207.

27. Velhner M, Mitevski D, Potkonjak D, Stojanović D, Kovačević M, Petrović $T$ et al., 2010, Biological properties of naturally attenuated infectious bursal disease virus isolated from backyard chicken flock, Acta Vet Hung, 58, 483-98.

28. Xue CJ, Wang GH, Chen F, Zhang XB, Bi YZ, Cao YC, 2010, Immunopathological effects of ochratoxin A and T-2 toxin combination on broilers, Poult Sci, 89, 1162-6. 


\title{
EFIKASNOST DETOKSIKUJUĆEG AGENSA KOD T-2 TOKSIKOZE BROJLERA
}

\author{
NEŠIĆ V, RESANOVIĆ RADMILA, MARINKOVIĆ D, NEŠIĆ KSENIJA, LAZAREVIĆ M, \\ NEŠIĆ S i ALEKSIĆ-KOVAČEVIĆ SANJA
}

\begin{abstract}
SADRŽAJ
U cilju ispitivanja efikasnosti detoksikujućeg agensa Mycofix ${ }^{\circledR}$ Plus (MP) na preveniranje ili ublažavanje štetnih efekata T-2 toksikoze kod brojlera izvedena su ispitivanja u in vitro uslovima, kao i in vivo ogled. Prosečne vrednosti degradacije T-2 toksina od strane MP $\mathrm{u}$ in vitro uslovima, ustanovljene HPTLC metodom, su iznosile 26,06 do $31,02 \%$, pri čemu je konstatovana veća sposobnost adsorpcije ovog toksina u kiseloj sredini ( $\mathrm{pH} 3$ ). In vivo ogled je bio postavljen na 160 jednodnevnih brojlera provenijencije „Ross“, podeljenih u 4 eksperimentalne grupe sa po 40 jedinki u svakoj i trajao je 21 dan. Praćenjem zdravstvenog stanja, kliničke slike i proizvodnih rezultata, kod brojlera koji su u hrani dobijali umešan T2 toksin u količini od $2 \mathrm{mg} / \mathrm{kg}$, konstatovani su karakteristični simptomi za T-2 toksikozu. Kod brojlera koji su uz toksin, hranom dobijali i MP, konstatovani su zaštitni efekti u vidu izostanka ulceracija u usnoj duplji i boljih proizvodnih rezultata u odnosu na brojlere koji su dobijali samo T-2 toksin.

Patohistološkim ispitivanjima uočeni su negativni efekti T-2 toksina u svim ispitivanim organima u vidu degenerativnih promena na sluzokoži usne duplje i tankog creva, nekroza enterocita i hepatocita kao i deplecija limfocita u Fabricijevoj burzi. Imunohistohemijskim ispitivanjima uočeni su negativni efekti T-2 toksina na proliferativnu aktivnost ćelija mukoze creva, žučnih kanala i limfocita u Fabricijevoj burzi. Kod brojlera koji su putem hrane dobijali T-2 toksin i adsorbens MP, zapaža se uglavnom očuvana makroskopska i mikroskopska struktura jetre, creva i Fabricijeve burze. Reakcija kožne preosetljivosti na PHA je bila slabija kod brojlera koji su hranom dobijali samo T-2 toksin.
\end{abstract}

